\title{
Nutritional and Developmental Regulation of Plasma Leptin in Dairy Cattle ${ }^{1}$
}

\author{
S. S. Block, J. M. Smith, R. A. Ehrhardt, M. C. Diaz, R. P. Rhoads, \\ M. E. Van Amburgh, and Y. R. Boisclair* \\ Department of Animal Science, Cornell University, Ithaca, NY 14853
}

\section{ABSTRACT}

Leptin is thought to play a critical role in regulating energy metabolism throughout mammalian life. In growing dairy cattle, plasma leptin has been proposed as a partial mediator of the effects of nutrition on reproductive and mammary development. However, the developmental stage at which the plane of nutrition increases plasma leptin has not been well defined. Further, it is unknown whether the onset of puberty is affected by plasma leptin concentration in dairy cattle. To investigate these questions, two studies were performed. In the first study, neonatal calves were fed a milk replacer at levels supporting an average daily gain of $570 \mathrm{~g} / \mathrm{d}(\mathrm{L})$ or $1210 \mathrm{~g} / \mathrm{d}(\mathrm{H})$. Weekly blood samples were obtained until slaughter at $105 \mathrm{~kg}$ of body weight. Plasma leptin and adiposity remained constant in the $\mathrm{L}$ calves, but started to increase by the third week of age in the $\mathrm{H}$ calves. In the second study, 3- to 5-mo-old heifers were fed a total mixed ration supplemented with either calcium salts of palm fat or conjugated linoleic acids at levels sustaining an average daily gain of approximately $1.0 \mathrm{~kg} / \mathrm{d}$. Blood samples were obtained until the third postpubertal luteal phase. The fat source had no effects on growth parameters, body composition, age at puberty, or plasma leptin. Therefore, plasma leptin was reanalyzed as a function of age from start of treatment until slaughter. The plasma concentration of leptin remained nearly constant at $2.3 \mathrm{ng} / \mathrm{ml}$ until 1 $\mathrm{yr}$ of age, when a rise in plasma leptin became obvious. Puberty occurred with equal frequency either around $1 \mathrm{yr}$ of age when plasma leptin was nearly constant or later when leptin was rising rapidly. We conclude that plasma leptin is regulated by nutrition in early postnatal life, but that a sudden increase in plasma leptin is not required for the onset of puberty in dairy cattle.

(Key words: leptin, nutrition, puberty, development)

\footnotetext{
Received January 20, 2003.

Accepted April 4, 2003.

Corresponding author: Y. R. Boisclair; e-mail: yrb1@cornell.edu.

${ }^{1}$ Supported by the National Research Initiative Competitive Grant Program, USDA CREES 00-35206-9352 (to Y. R. B.) and by the Cornell University Agricultural Experiment Station.
}

Abbreviation key: ADG = average daily gain, $\mathbf{C L A}=$ conjugated linoleic acids, $\mathbf{G H}=$ growth hormone, $\mathbf{H}=$ high plane of nutrition, $\mathbf{L}=$ low plane of nutrition, RIA $=$ radioimmunoassay, $\mathbf{W A T}=$ white adipose tissue.

\section{INTRODUCTION}

In ruminants, the protein hormone leptin is secreted almost exclusively by white adipose tissue (WAT) (Chilliard et al., 2001; Ingvartsen and Boisclair, 2001). Leptin acts predominantly on isolated regions of the brain, where it serves as a satiety signal, as shown by hyperphagia of leptin-deficient humans and mice, and by reduced feed intake in leptin-treated animals, including ruminants (Henry et al., 1999; Ahima and Flier, 2000; Farooqi et al., 2002). In addition, plasma leptin is increased by adiposity and is higher in females than in males (Saad et al., 1997; Ehrhardt et al., 2000). Plasma leptin is also reduced rapidly during periods of undernutrition (Ahima and Flier, 2000; Ingvartsen and Boisclair, 2001). This observation has led Flier and colleagues to suggest that a second role may be to regulate neuroendocrine mechanisms responsible for the partitioning of energy (Flier, 1998; Ahima and Flier, 2000; Spiegelman and Flier, 2001). According to this model, low plasma leptin due to depleted fat reserves or nutritional insufficiency, promotes conservation of energy at the expense of dispensable functions such as reproduction and immunity (Ahima and Flier, 2000; Faggioni et al., 2001).

The regulation and roles of plasma leptin have been studied predominantly in adult animals, and almost always in the context of diseases such as obesity or diabetes (Ahima and Flier, 2000; Ingvartsen and Boisclair, 2001; Spiegelman and Flier, 2001). Very little information is available in early postnatal life in any animals. This information would be particularly useful in growing dairy cattle because variations in the plane of nutrition impact developmental processes that could be regulated by leptin. For example, high planes of nutrition lead to earlier onset of puberty and younger age at calving (Foster and Nagatani, 1999; Sejrsen et al., 2000). In prepubertal heifers, however, the use of this nutritional strategy has also been associated with 
decreased parenchymal mammary development and decreased future milk yield (Sejrsen et al., 2000). Cues mediating these effects of nutrition remain unknown, but leptin is an attractive candidate given the positive relation between its synthesis and nutrition.

As a first step to evaluate the role of leptin in early postnatal life, we sought to determine the developmental and nutritional regulation of leptin in growing dairy cattle. We also asked whether variation in plasma leptin concentration could explain variation in the onset of puberty in a group of well-fed dairy heifers. Our data indicate that nutrition regulates plasma leptin soon after birth, but that puberty can occur over a wide range of plasma leptin concentrations.

\section{MATERIALS AND METHODS}

\section{Animals and Design}

All experimental procedures were conducted with the approval of the Cornell University Institutional Animal Care and Use Committee. Holstein bulls and heifers were purchased from commercial dairy farms. They were housed at the Cornell University Teaching and Research facility in individual stalls under ambient light and temperature.

Immediate postnatal period. To describe the ontogeny of plasma leptin after birth, a previously described study was used (Diaz et al., 2001). Animals consisted of dairy bulls born in January and February of the same year. They were fed $3.7 \mathrm{~L}$ of colostrum at birth and transported to the Cornell Teaching and Research facility within the next $24 \mathrm{~h}$. Upon arrival, calves were fed a colostrum supplement (Lifeline, American Protein Corp., Ames, IA), administered vitamin B complex (The Butler Co., Dublin, OH), selenium, and vitamin E (BoSe, Schering-Plough Animal Health Corp., Union, NJ), elemental iron (The Butler Co.) and vaccinated according to the research protocol (TSV-2, Pfizer Animal Health, Exton, PA; Once PMH and BRSV Vac 4, Bayer Corp., Shawnee Mission, KS).

After 3 to $5 \mathrm{~d}$ of adjustment to housing conditions, calves were randomly allocated to one of nine treatments arranged in a $3 \times 3$ factorial (six animals per treatment). The first factor consisted of plane of nutrition targeted to sustain average daily gains (ADG) of 0.50 (low), 0.95 (medium), or $1.4 \mathrm{~kg} / \mathrm{d}$ (high). All animals were fed appropriate amounts of a single reconstituted milk replacer (300 g of CP, $200 \mathrm{~g}$ of fat, and approximately $440 \mathrm{~g}$ of carbohydrate and $60 \mathrm{~g}$ of ash per $\mathrm{kg}$ DM; Milk Specialties Company, Dundee, IL). Daily allowances were fed in three equal meals at 0700, 1400 and $2100 \mathrm{~h}$; water was available at all times. The second factor consisted of weight at slaughter $(65,85$, and 105 $\mathrm{kg}$ ). For the purpose of the present study, analysis was restricted to three nutrition $\times$ BW combinations [Low$65 \mathrm{~kg}$ (L-65); Low-105 kg, (L-105); and High-105 kg, (H-105)]. This arrangement allowed the comparison of the low $(\mathbf{L})$ and high $(\mathbf{H})$ planes of nutrition at the same body size (L-105 vs. H-105) and at a comparable chronological age (L-65 vs. H-105). Weekly blood samples were obtained by jugular venipuncture between 1100 and $1300 \mathrm{~h}$. Plasma was prepared immediately and frozen at $-20^{\circ} \mathrm{C}$ until analyzed. Calves were killed by captive bolt stunning and exsanguination when they reached their target weight (between early March and late May).

Ruminant growth phase. A second study was used to describe the ontogeny of plasma leptin in dairy heifers from shortly after weaning until puberty. All animals were born between January and March of the same year. They were brought to the Cornell Teaching and Research facility at 3 to $5 \mathrm{~m}$ of age, and acclimatized for a period of $3 \mathrm{wk}$. During that time, they were fed a silage-based TMR ad libitum and were vaccinated against infectious bovine rhinotracheitis, parainfluenza type 3, bovine viral diarrhea, and bovine respiratory syncytial viruses (Bovishield 4, Pfizer Animal Health), clostridial diseases (Ultrabac 7, Pfizer Animal Health), and Pastuerella pneumonia (One Shot, Pfizer Animal Health). Vaccination was repeated 4 wk later.

Twelve animals were randomly allocated to a TMR containing $2.6 \%$ of a calcium salt of palm fatty acids (control; Ener GII, Bioproducts Inc., Fairlawn, OH) or $2.8 \%$ of a calcium salt of conjugated linoleic acid (CLA; Natural Lipids, Hovdebygda, Norway). Each treatment was designed to provide equal amounts of fatty acids. The control fat supplement contained $85 \%$ fat and $8.5 \%$ $\mathrm{Ca}$, with palmitic, oleic, and linoleic fatty acids accounting for 46,38 , and $11 \%$ of total fatty acids, respectively. The CLA supplement contained $75 \%$ fat and $17 \% \mathrm{Ca}$, with CLA isomers accounting for $39 \%$ of the fatty acids; the most abundant CLA isomers present were trans10, cis-12, and cis-9, trans-11 CLA (28 and $23 \%$ of total CLA, respectively). Diets were formulated using the Cornell Net Carbohydrate and Protein System to provide sufficient metabolizable energy and metabolizable protein to sustain a daily gain of $1 \mathrm{~kg} / \mathrm{d}$ (CNCPS v. 4.0; Fox et al., 2000). Heifers were weighed weekly, and daily feed allowances were adjusted to sustain gains of $1 \mathrm{~kg} / \mathrm{d}$.

Blood samples were obtained via jugular venipuncture into evacuated blood collection tubes containing sodium heparin on a weekly basis prior to $225 \mathrm{~kg}$ of BW, and twice weekly thereafter. Plasma was prepared immediately and frozen at $-20^{\circ} \mathrm{C}$ until analyzed. Individual animals were declared pubertal when the plasma concentration of progesterone exceeded $1 \mathrm{ng} / \mathrm{ml}$ in two consecutive samples. Animals were killed during 
diestrus of their third estrous cycle by captive bolt stunning and exsanguination.

\section{Analysis of Body Composition}

Animals were partitioned into four components representing blood and organs; head, hide, feet, and tail; liver; and carcass (Diaz et al., 2001). Blood and organs comprised kidneys, spleen, pancreas, bladder, reproductive tract, heart-lungs-trachea, blood, and digestive tract (rumen, reticulum, omasum, abomasum, large, and small intestine). The digestive tract was emptied of digesta before inclusion in blood and organs. Weights of all four components were recorded before they were ground separately; however, in the ruminant growth phase study, the liver was included with the blood and organs fraction. Representative samples of each component were freeze-dried and stored until measurement of fat by ether extraction as described previously (Diaz et al., 2001).

\section{Analysis of Metabolites and Hormones}

Plasma glucose was measured by the glucose oxidase method and NEFA by the Acyl-CoA synthetase/oxidase method (Block et al., 2001). Plasma leptin was assayed by a double antibody bovine radioimmunoassay (RIA) (Ehrhardt et al., 2000; Block et al., 2001). Plasma concentrations of progesterone, insulin, growth hormone (GH), and IGF-I were measured by specific RIA established in our laboratory (Boisclair et al., 1994; Beam and Butler, 1997); inter and intraassay CV for all assays averaged less than 8 and $10 \%$, respectively.

\section{Statistical Analysis}

All data were analyzed using the mixed model procedure of SAS (SAS Institute, Cary, NC). In both studies, changes over time were assessed using a mixed model accounting for time and treatment as the fixed effects, and animal as the random effect. When considering fixed end points (slaughter or puberty), data were analyzed with a mixed model with treatment as the fixed effect (i.e., L-105, L-65, and H-105; control or CLA) and animal as the random effect. Relations between the plasma concentration of leptin and indices of body composition, plasma metabolites, or age were assessed by linear regression.

\section{RESULTS}

\section{Immediate Postnatal Period}

Actual growth rates for the calves offered the $\mathrm{L}$ and $\mathrm{H}$ plane of nutrition were 0.57 and $1.21 \mathrm{~kg} / \mathrm{d}$, respec-

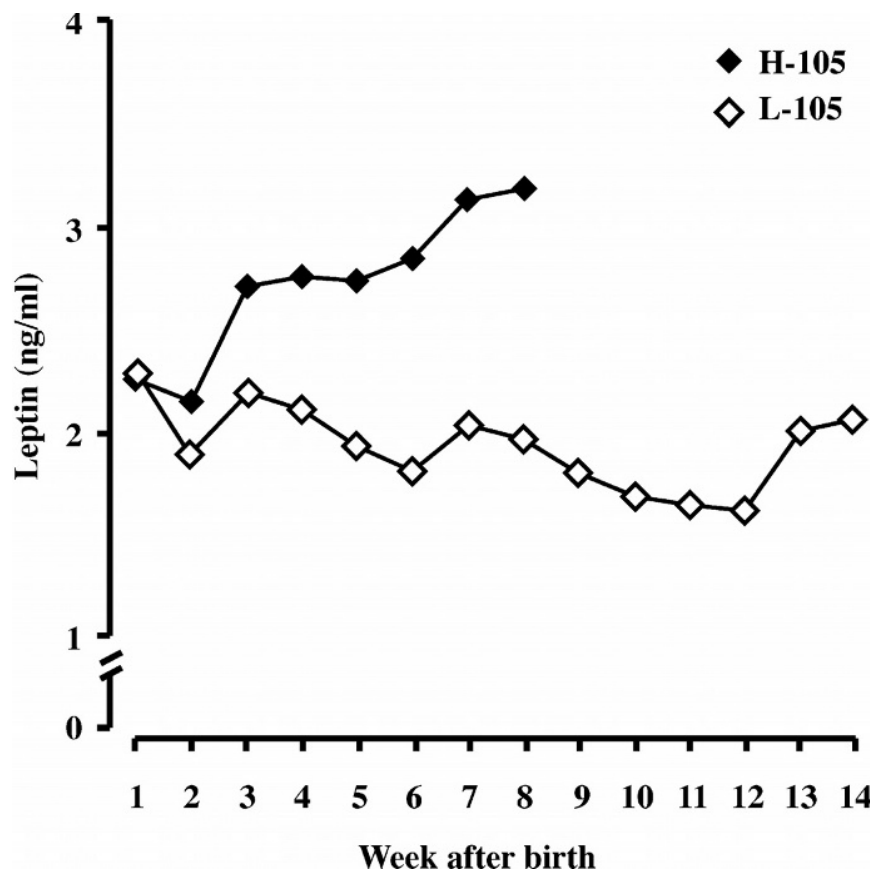

Figure 1. Effects of plane of nutrition on the ontogeny of plasma leptin in male Holstein calves. Newborn animals were fed to gain at target rates of 500 (L-105) or $1400 \mathrm{~g} / \mathrm{d}$ (H-105) until slaughter at 105 $\mathrm{kg}$ (six animals per treatment). Pooled SE was $0.43 \mathrm{ng} / \mathrm{ml}$.

tively $(P<0.01$; Diaz et al., 2001). Within the first week of treatment, plasma leptin concentration of $\mathrm{H}-105$ and L-105 calves did not differ and averaged $2.2 \mathrm{ng} / \mathrm{ml}$ (Figure 1). The profile of plasma leptin diverged for the first time at $3 \mathrm{wk}$ of age when plasma leptin started to rise in the H-105 group (treatment $\times$ time; $P<0.001$ ). Plasma leptin concentration continued to increase over time in the $\mathrm{H}-105$ calves, whereas it decreased in the L-105 kg calves until it rebounded above $2 \mathrm{ng} / \mathrm{ml}$ during the last 2 wk.

At slaughter, plasma leptin concentration was $52 \%$ higher in the H-105 than in the L-105 group (Figures 1 and $2 ; P<0.001)$. The $\mathrm{H}-105$ calves were nearly twice as fat as the L-105 (Figure 2; $P<0.001$ ), but because of their faster rate of gain, were also younger than the L-105 calves ( $48 \pm 5$ vs. $94 \pm 3$ d; $P<0.01$ ). To compare the effect of nutrition on a chronological basis, plasma leptin and body fat were measured in a group of animals receiving the low plane of nutrition and slaughtered at $65 \mathrm{~kg}$ (L-65), when about the same age as the H-105 calves $(39 \pm 5 \mathrm{~d})$. Plasma leptin and body fat of L-65 calves were identical to those of L-105, and again lower than those of $\mathrm{H}-105$ (Figure 2). These data suggest that plasma leptin fails to increase in the $\mathrm{L}$ calves over time because their body fat content is static.

Plasma samples obtained $3 \mathrm{~d}$ before slaughter were used to determine whether the concentration of leptin 

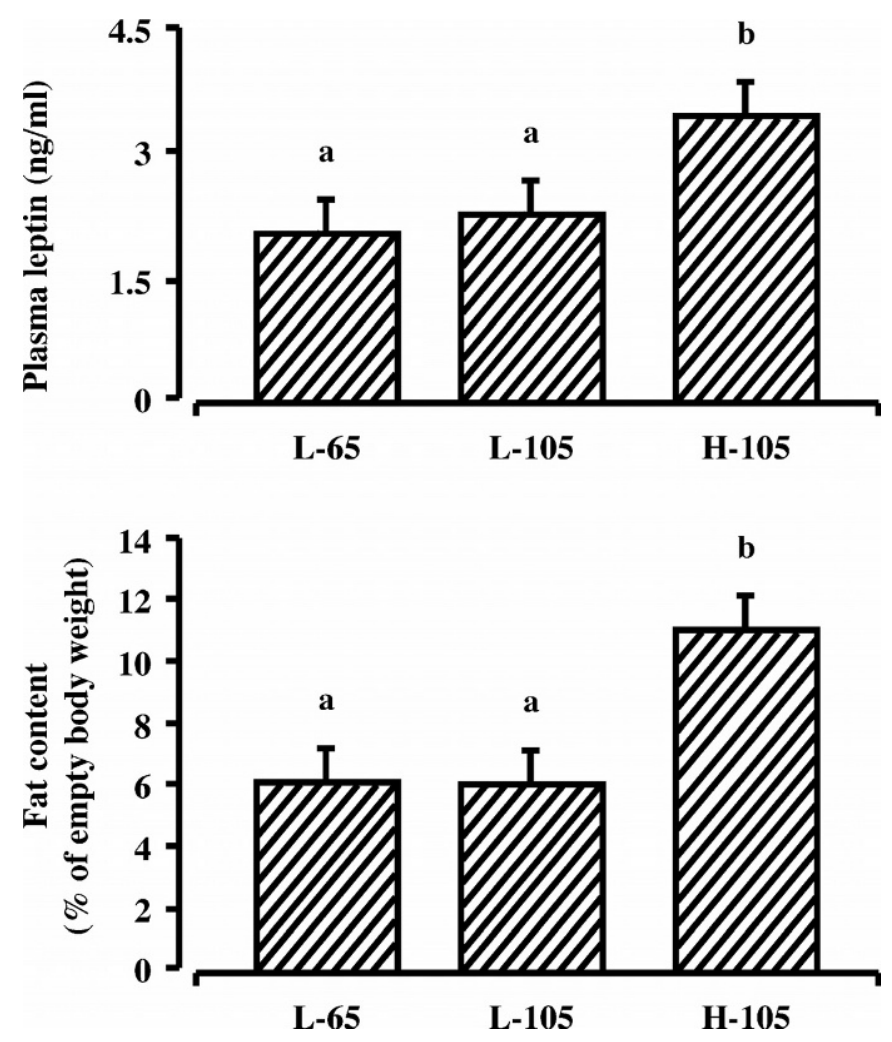

Figure 2. Effect of plane of nutrition on plasma leptin and fat content in male Holstein calves. Newborn animals were fed to grow at a target rate of $500 \mathrm{~g} / \mathrm{d}$ and slaughtered at 65 (L-65) or $105 \mathrm{~kg}$ (L$105)$, or fed to gain at $1400 \mathrm{~g} / \mathrm{d}$ and slaughtered at $105 \mathrm{~kg}$ (H-105). Leptin was analyzed in samples collected $3 \mathrm{~d}$ before slaughter. Age at slaughter for the L-65, H-105, and L-105 groups were $39 \pm 5,48$ \pm 5 , and $94 \pm 3 \mathrm{~d}$, respectively. Mean $\pm \mathrm{SE}$ is shown for each group $(\mathrm{N}=6)$. Bars with different letters differ at $P<0.001$.

was related to those of other hormones and metabolites. The concentration of plasma leptin was positively correlated with the concentration of insulin and IGF-I (Figure $3 ; P<0.01$ ) and tended to be correlated positively with plasma glucose $(\mathrm{P}<0.07)$. The concentration of plasma leptin was not correlated with the plasma concentrations of NEFA or GH (data not shown).

\section{Ruminant Growth Phase}

To examine the ontogeny of plasma leptin until the onset of puberty, a study originally designed to examine the effects of dietary CLA on growth of prepubertal dairy heifers was used. Conjugated linoleic acid did not alter average daily gain (control vs. CLA, $0.97 \pm 0.08$ vs. $0.92 \pm 0.06 \mathrm{~kg} / \mathrm{d} ; P>0.27$ ), or age at puberty (control vs. CLA, $364 \pm 69$ vs. $337 \pm 77 \mathrm{~d} ; P>0.53$ ) (Smith et al., unpublished). Similarly, CLA had no effect on live weight at puberty (control vs. CLA, $344 \pm 70$ vs. $320 \pm$ $55 \mathrm{~kg} ; P>0.61$ ) or fat content of the empty body at

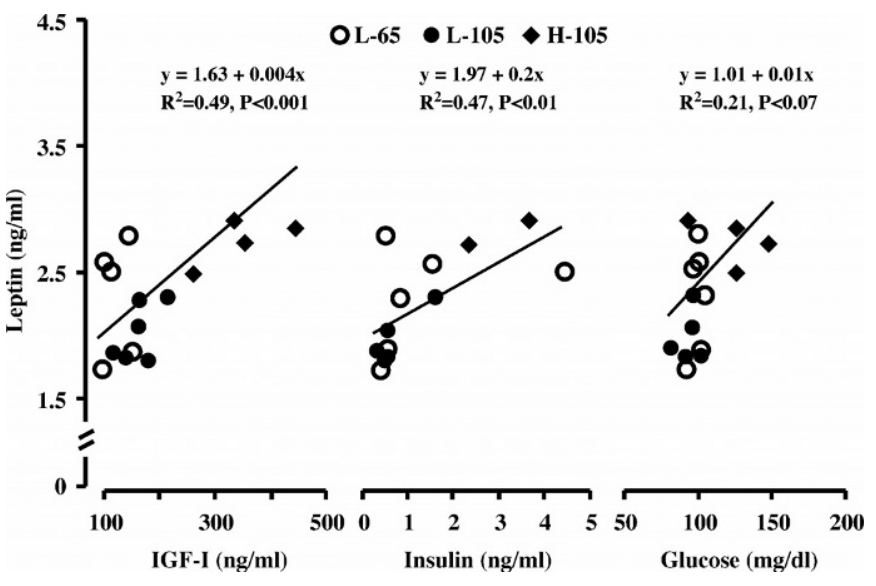

Figure 3. Relationships between the concentrations of leptin and other variables in plasma of male Holstein calves. Newborn animals were fed to grow at a target rate of $500 \mathrm{~g} / \mathrm{d}$ and slaughtered at 65 (L-65) or $105 \mathrm{~kg}$ (L-105), or to grow at a target rate of $1400 \mathrm{~g} / \mathrm{d}$ and slaughtered at $105 \mathrm{~kg}$ (H-105). Each group consisted of six calves. Plasma concentrations were measured $3 \mathrm{~d}$ prior to slaughter.

slaughter (control vs. CLA, $21 \pm 3$ vs. $19 \pm 2 \% ; P>0.18$ ). Before initiation of treatment (wk 0), plasma leptin, insulin, and GH were similar for both groups (Figure 4). Over the first $20 \mathrm{wk}$ of treatment, CLA had no effect on plasma leptin or GH but caused a small, consistent decrease in plasma insulin $(P<0.05$, Figure 4$)$. Similar results were obtained after 20 wk of treatment, when the slaughter of pubertal animals caused a progressive dwindling in the number of observations (results not shown).

Data were also analyzed as a function of age from start of treatment until slaughter. Again, CLA had no effect on this relationship, so data were pooled across treatments. Plasma leptin averaged $\sim 2.3 \mathrm{ng} / \mathrm{ml}$ until d 300 of age, when it started to increase rapidly (Figure 5). At slaughter, plasma leptin concentration was positively correlated with percentage of fat in the carcass, total kilograms of fat and final BW (Figure 6, $P \leq 0.01$ ), but not with plasma GH or insulin (results not shown). These data suggest that the curvilinear relationship between plasma leptin and age reflects an increased rate of fat deposition as animals approach mature size (Figure 5).

Age at puberty followed a bimodal distribution, with six heifers reaching puberty between d 236 and 309 of age (early puberty, $286 \pm 27 \mathrm{~d}$ ), and six heifers reaching puberty between d 393 and 445 of age (late puberty, $414 \pm 22 \mathrm{~d}$ ); control and CLA heifers were equally represented in each group. When analyzed according to onset of puberty, the early puberty heifers were significantly lighter and leaner than the late puberty heifers $(P<$ 0.05 , Table 1). Moreover, the plasma concentration of leptin was significantly lower in the early puberty than 

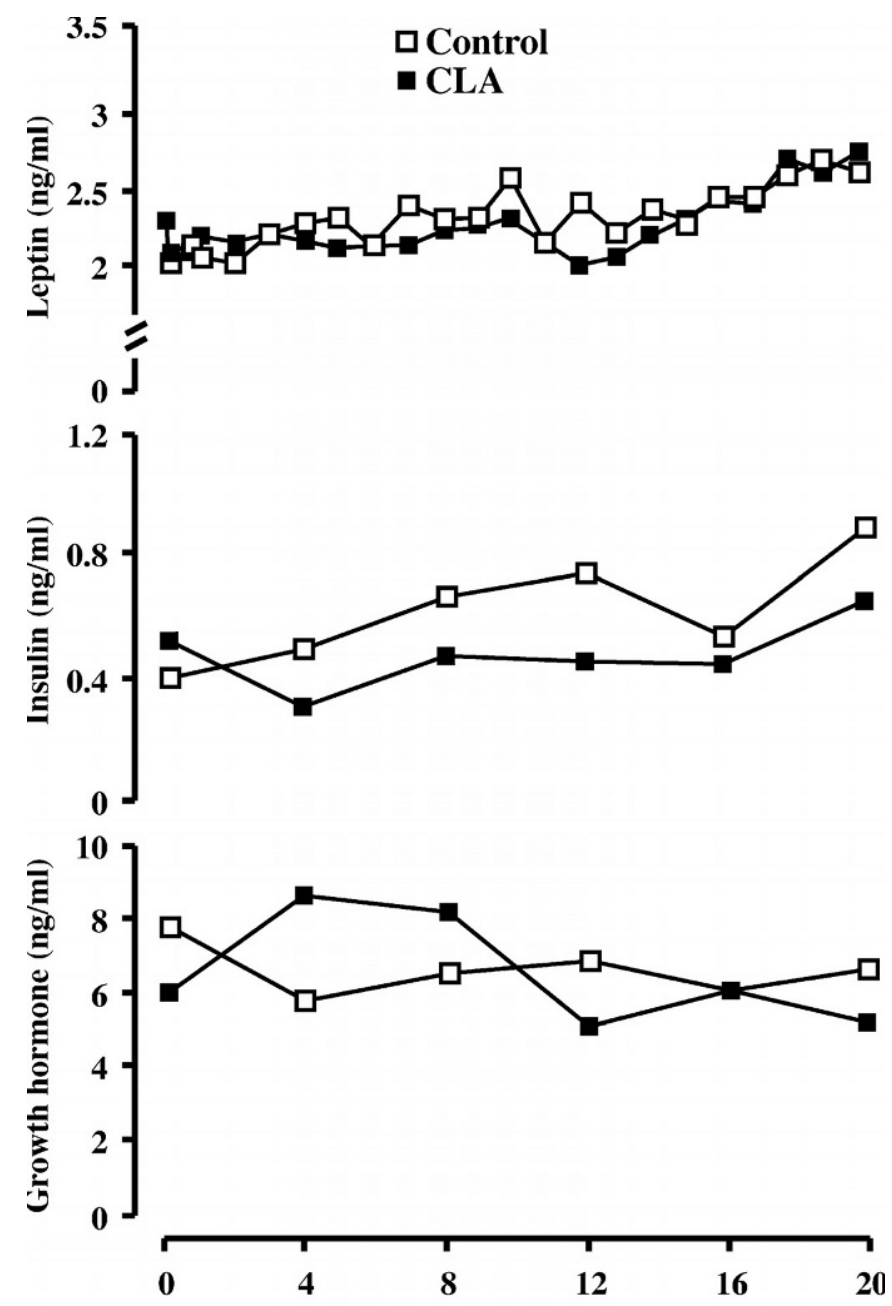

Time on treatment (wk)

Figure 4. Effect of fat supplementation on plasma hormones in growing dairy heifers. Holstein heifers were fed diets containing equivalent amounts of a control fat or CLA supplement $(n=6$ per treatment). Treatments were initiated immediately after obtaining blood samples at wk 0 and lasted until puberty. Data presented were collected before the loss of any animals due to puberty. The concentration of leptin (top panel) was assayed on a weekly basis, whereas the plasma concentrations of insulin (middle panel) and growth hormone (bottom panel) were assayed every 4 wk. Pooled $\mathrm{SE}$ for plasma leptin, insulin, and GH were $0.2,0.1$ and $1.5 \mathrm{ng} /$ $\mathrm{ml}$, respectively.

in the late puberty group (Table $1, P<0.001$ ), whereas the plasma concentrations of insulin and GH did not differ.

To explore the possibility that the rate of change, rather than the absolute plasma concentration of leptin, is the important biological input for puberty, the profile of plasma leptin was characterized for both groups around puberty (Figure 7). The plasma concentration of leptin was nearly constant around puberty in the early puberty heifers, whereas it increased in the late

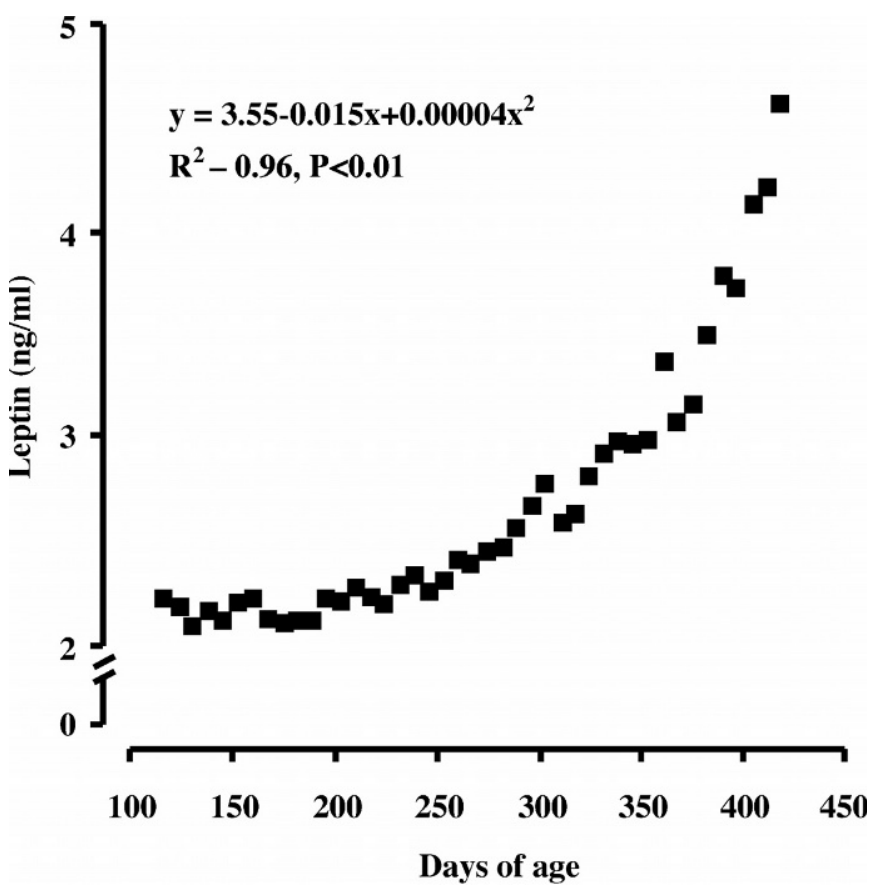

Figure 5. Effect of age on the concentration of plasma leptin in growing dairy heifers. Holstein heifers were fed a diet containing equivalent amounts of control fat supplement or CLA supplement ( $\mathrm{n}$ $=6$ per treatment). Because type of fat supplementation had no effect, the weekly averages of plasma leptin were pooled across treatment and plotted as a function of age. Between d 158 and 298 of age, each point represents the average of 12 animals. Before d 158 and after d 298 they represent a minimum of six animals. Pooled SE was 0.1 $\mathrm{ng} / \mathrm{ml}$.

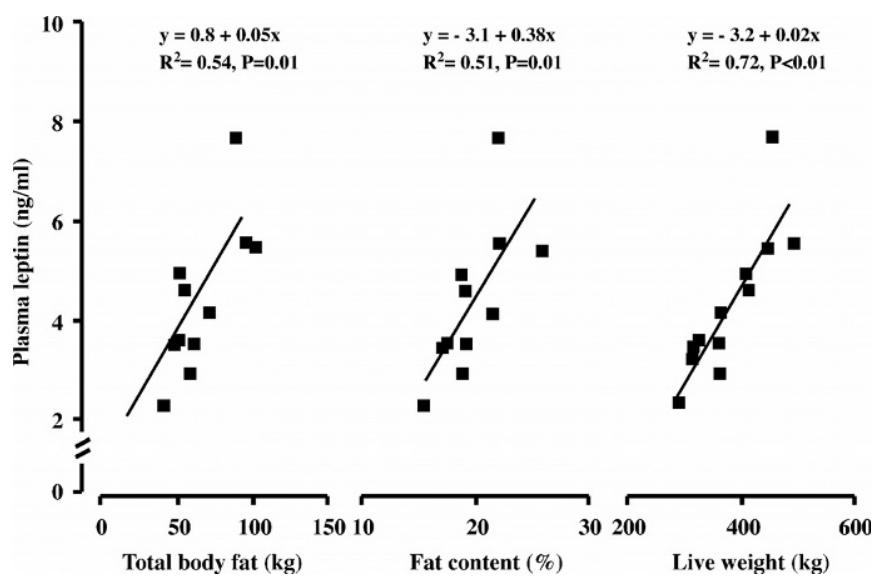

Figure 6. Relationships between plasma leptin and various indices of fatness in pubertal dairy heifers. Holstein heifers were fed diets containing equivalent amounts of a control fat supplement or CLA supplement ( $\mathrm{n}=6$ per treatment). They were slaughtered during the third luteal phase. Plasma leptin represents the average of biweekly samples collected over the last two weeks prior to slaughter. Fat content was measured in the empty BW. 
Table 1. Growth parameters and hormones in heifers grouped according to timing of puberty.

\begin{tabular}{lcllc}
\hline & \multicolumn{4}{c}{ Puberty $^{1}$} \\
\cline { 2 - 5 } & $\begin{array}{l}\text { Late } \\
\text { Early } \\
\text { puberty }\end{array}$ & $\begin{array}{l}\text { puberty } \\
\text { at 286 d }\end{array}$ & $\begin{array}{l}\text { Late } \\
\text { puberty }\end{array}$ & SE \\
\hline BW (kg) & $280^{\mathrm{a}}$ & $254^{\mathrm{a}}$ & $384^{\mathrm{b}}$ & 26 \\
Age, days & $286^{\mathrm{a}}$ & $286^{\mathrm{a}}$ & $414^{\mathrm{b}}$ & 20 \\
Fat content ${ }^{2}(\%)$ & $17.7^{\mathrm{d}}$ & - & $21.6^{\mathrm{e}}$ & 0.02 \\
Hormones & & & & \\
Progesterone (ng/ml) & $2.3^{\mathrm{a}}$ & $0.1^{\mathrm{b}}$ & $3.9^{\mathrm{c}}$ & 0.5 \\
Growth hormone (ng/ml) & $5.6^{\mathrm{a}}$ & $6.1^{\mathrm{a}}$ & $6.2^{\mathrm{a}}$ & 2.4 \\
Insulin (ng/ml) & $1.2^{\mathrm{a}}$ & $0.8^{\mathrm{a}}$ & $1.0^{\mathrm{a}}$ & 0.8 \\
Leptin (ng/ml) & $2.6^{\mathrm{a}}$ & $2.4^{\mathrm{a}}$ & $4.3^{\mathrm{b}}$ & 0.4 \\
\hline
\end{tabular}

a,b,c Means with different superscripts differ at $P<0.001$.

${ }^{\mathrm{d}, \mathrm{e}}$ Means with different superscripts differ at $P<0.01$.

${ }^{1}$ For the early puberty and late puberty groups, values represent the averages of samples collected during the $7 \mathrm{~d}$ prior and $7 \mathrm{~d}$ after onset of the first full luteal phase. Late puberty at $286 \mathrm{~d}$ represents data collected from late puberty heifers during the $7 \mathrm{~d}$ prior and 7 $\mathrm{d}$ after $286 \mathrm{~d}$ of age.

${ }^{2}$ Measured in the empty BW.

puberty heifers (age at puberty $\times$ time, $P<0.0001$ ). Moreover, when analyzed at the age when puberty occurred in the early puberty group (d 286), BW, mean

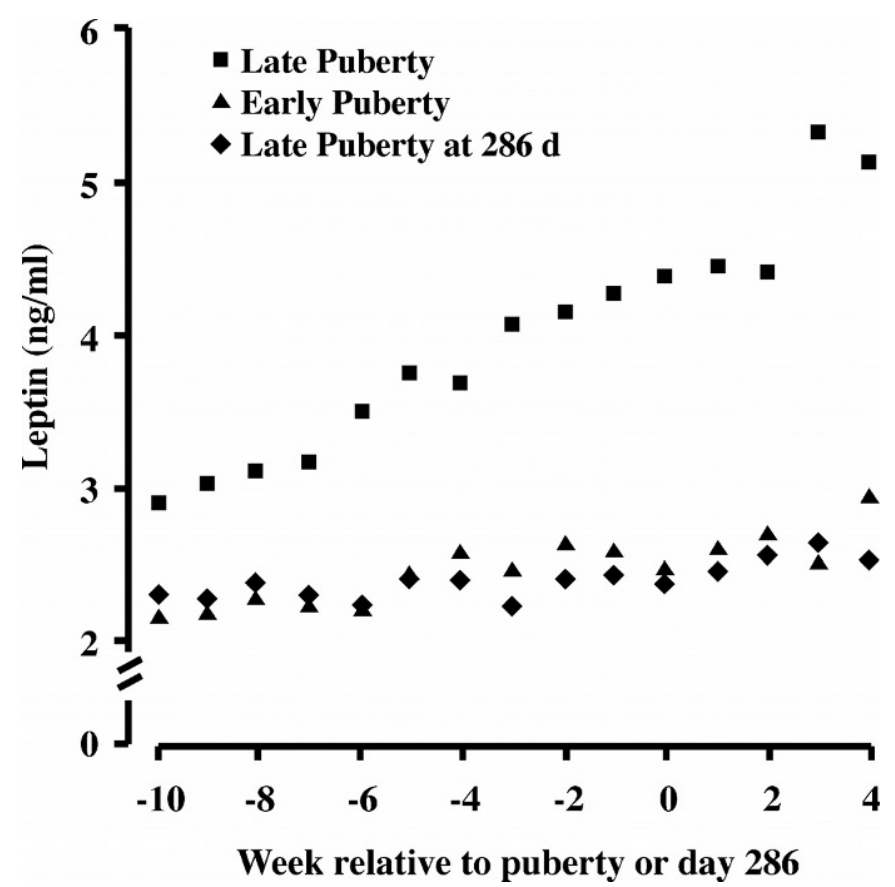

Figure 7. Peripubertal profile of plasma leptin in early pubertal and late pubertal heifers. The concentration of plasma leptin around puberty (wk $0=$ puberty) is represented for heifers with early onset (early puberty; $286 \pm 27 \mathrm{~d}$ ) or late onset (late puberty; $414 \pm 22 \mathrm{~d}$ ). Plasma leptin of late puberty heifers is also represented at the age of $286 \mathrm{~d}$ (wk $0=286 \mathrm{~d}$; late puberty at $286 \mathrm{~d}$ ), which is the age at which puberty occurred in the early puberty group. Pooled SE was $0.2 \mathrm{ng} / \mathrm{ml}$. plasma leptin, and the profile of plasma leptin of the late puberty heifers were identical to those of early puberty heifers (late puberty at $286 \mathrm{~d}$ vs. early puberty, Table 1 and Figure 7). These data indicate that failure to reach puberty early is not explained by a deficit in any of these variables. Overall, these data suggest that plasma leptin does not determine the timing of puberty.

\section{DISCUSSION}

Leptin has been proposed to mediate some of the effects of nutrition on reproductive and mammary development of cattle (Garcia et al., 2002; Silva et al., 2002; Williams et al., 2002). An assumption implicit in these models is positive nutritional regulation of plasma leptin. This has been convincingly demonstrated in juvenile and mature ruminants (Chilliard et al., 2001; Ingvartsen and Boisclair, 2001), but until now, this evidence is lacking in growing dairy cattle.

The effect of nutrition on circulating leptin during fetal life has not been studied in cattle, but data in sheep suggest that this is unlikely to occur. In that species, the concentration of leptin in fetal plasma is not regulated by moderate variations in maternal nutrition ( $\pm 50 \%$ of requirements), even when imposed during late gestation (Ehrhardt et al., 2002; Mühlhäusler et al., 2002; Yuen et al., 2002). This lack of regulation likely reflects the low adiposity of fetal ruminants (Alexander, 1978; Diaz et al., 2001), and the significant production of leptin by nonadipose tissue where synthesis may not be nutritionally regulated (Ehrhardt et al., 2002). Our data indicate that, in cattle, this state of nonresponsiveness extends to the first 2 wk of postnatal life. By the third week, however, plasma leptin started to rise in male calves receiving the high plane of nutrition. This actually corresponds to the time at which these animals display a significant elevation in fatness relative to birth (Diaz et al., 2001). In contrast, male calves fed according to currently accepted standards (i.e., L calves gaining $0.57 \mathrm{~kg} / \mathrm{d}$; NRC 2001) had static adiposity and plasma leptin concentration. We anticipate that female calves would yield similar results, given that the pattern of growth this early in life is virtually the same for both sexes (Kuehn et al., 1994). The same may be true in sheep because conventionally fed lambs (unrestricted suckling and access to a dry diet) have constant plasma leptin between $\mathrm{d} 19$ and 47 of postnatal life (McFadin et al., 2002), whereas lambs fed on a high plane of nutrition have two to threefold higher levels of plasma leptin than those on a low plane of nutrition (Ehrhardt et al., 2001). Overall, our data indicate that plasma leptin in dairy cattle can be increased by nutrition in early postnatal life, but that currently recom- 
mended feeding standards do not support increased adiposity and the associated rise in plasma leptin.

The ruminant phase of growth was studied in heifers offered either a conventional or a CLA-enriched fat supplement. During the acclimatization phase of this experiment, they were fed according to recommended standards, and their concentration of plasma leptin averaged $2.2 \mathrm{ng} / \mathrm{ml}$. Chronic CLA supplementation had no effects on growth, adiposity, or fat accumulation, and not surprisingly, no effect on plasma leptin. The absence of CLA effects was not totally unexpected because a substantial portion must have been destroyed by rumen fermentation and because attenuation of lipogenesis requires a higher dose of CLA in WAT than in the mammary gland, as recently discussed by Baumgard et al. (2002). Nevertheless, this general lack of effect provided the opportunity to study the ontogeny of plasma leptin until puberty. Plasma leptin remained nearly constant until d 300, which, developmentally, corresponds to the time when deposition of lean tissue slows down and nutrients become increasingly partitioned towards lipogenesis. These results suggest that, as shown in the preruminant calves, rapidly rising concentrations of plasma leptin are most obvious when the rate of fat accretion increases.

In many mammals, including cattle, undernutrition is a potent negative modulator of reproductive activity (Foster and Nagatani, 1999; Spicer, 2001; Williams et al., 2002). In the growing animal, suboptimal nutrition delays growth, the acquisition of adequate energy stores and puberty (Foster and Nagatani, 1999). Moreover, leptin-deficient mice and humans are in a permanent prepubertal state, and leptin therapy alone is sufficient for resumption and completion of sexual development (Chehab et al., 1996; Mounzih et al., 1997; Farooqi et al., 1999). These observations have led to the hypothesis that leptin could be a primary signal triggering puberty (Foster and Nagatani, 1999). This model predicts that peripubertal animals should have higher plasma leptin than nonpubertal animals. Our data do not support this model because puberty occurred over a range of plasma leptin concentrations and equally well in the presence of static or increasing peripubertal plasma leptin concentrations. The peripubertal rise in plasma leptin reported by others probably reflects fat deposition (DiazTorga et al., 2001; Garcia et al., 2002) but is obviously not a mandatory condition for attainment of puberty in dairy cattle. In this context, the report by Diaz-Torga et al. (2001) should be viewed cautiously because plasma concentrations were assayed by a commercial RIA and were 15 to 30 times higher than those measured in ruminants using extensively validated homologous RIA (Delavaud et al., 2000; Ehrhardt et al., 2000). Finally, peripheral leptin administration can increase
LH pulsation in underfed, sexually mature sheep but does not trigger its appearance in prepubertal lambs (Jackson et al., 2002; Morrison et al., 2002). Therefore, a rise in plasma leptin is not the developmental event triggering the onset of puberty in ruminants. A similar conclusion has been reached in the rhesus monkey (Plant, 2001), and in mice and rats where puberty also occurs over a range of age and adiposity, and in the absence of any peripubertal change in plasma leptin (Devaskar et al., 1997; Bronson, 2001; Cheung et al., 2001; Engelbregt et al., 2001; Watanobe and Schioth, 2002)

An alternative hypothesis is that leptin is permissive to the occurrence of puberty. In this model, depressed plasma leptin, due to insufficient nutrient availability or depleted body reserve, attenuates the ability of other signals to trigger puberty, or even acts as an absolute gating mechanism (Cunningham et al., 1999). Consistent with this idea, leptin administration corrects the delay in puberty observed in feed-restricted rodents (Cheung et al., 1997, 2001). The minimally effective leptin concentration allowing puberty to occur has not been defined in any species, but appears to be quite low. As shown in this paper, plasma levels of $2.6 \mathrm{ng} /$ $\mathrm{ml}$ are sufficient for the occurrence of puberty in cattle. Similarly, timing of puberty is normal in lipoatropic humans, which have virtually no adipose tissue and plasma leptin levels below $1 \mathrm{ng} / \mathrm{ml}$ (Pardini et al., 1998; Andreelli et al., 2000).

Insulin is an important positive regulator of leptin synthesis in mature dairy cattle, as shown by positive correlations between their plasma levels, and by elevated plasma leptin during euglycemic-hyperinsulinemic conditions (Block et al., 2001, 2003; Leury et al., 2003). We confirmed the positive effects of insulin in the immediate postnatal period, but we failed to identify this relationship in pubertal heifers. We postulate that the latter reflects the lack of statistical power (narrow range of plasma leptin and insufficient number of animals). Nevertheless, this observation warrants investigations of the ability of insulin to regulate plasma leptin during the ruminant phase of growth in dairy cattle.

In prepubertal heifers, growth rates in excess of 700 $\mathrm{g} / \mathrm{d}$ have been associated with decreased mammary parenchymal growth, and with decreased milk yield during the first lactation (Radcliff et al., 2000; Sejrsen et al., 2000). In MAC-T cells, a SV-40 transformed mammary epithelial cell line derived from a lactating dairy cow (Huynh et al., 1991), leptin caused a $20 \%$ reduction in IGF-I stimulated thymidine incorporation (Silva et al., 2002). These observations have led to the idea that increased plasma leptin could be responsible for mediating the negative effects of nutrition on prepubertal 
mammary development. However, our data showing that ruminant heifers growing at $\sim 1 \mathrm{~kg} / \mathrm{d}$ maintain low and nearly constant level of plasma leptin during most of the prepubertal period are somewhat inconsistent with this idea. Moreover, negative effects of leptin on IGF-I mediated proliferation could not be demonstrated in primary epithelial cells isolated from prepubertal heifers (Purup and Sejrsen, 2000). However, it remains possible that mammary development was depressed in our study, and that local synthesis rather than plasma delivery is the primary determinant of leptin concentration in the vicinity of the developing mammary epithelium. In this context, leptin mRNA is readily detected in mammary WAT of growing dairy heifers (Block and Boisclair, unpublished results), but whether nutrition regulates leptin synthesis in mammary WAT remains to be shown.

In summary, plasma leptin can be increased under conditions leading to accelerated fat deposition in growing dairy cattle (i.e., higher plane of nutrition after birth, age-dependent shift in nutrient partitioning). An age-dependent increase in plasma leptin is not required for onset of puberty, but it remains possible that leptin modulates mammary parenchymal development.

\section{REFERENCES}

Ahima, R. S., and J. S. Flier. 2000. Leptin. Annu. Rev. Physiol. 62:413-437.

Alexander, G. 1978. Quantitative development of the adipose tissue of foetal sheep. Aust. J. Biol. Sci. 31:489-503.

Andreelli, F., H. Hanaire-Broutin, M. Laville, J. P. Tauber, J. P. Riou, and C. Thivolet. 2000. Normal reproductive function in leptindeficient patients with lipoatropic diabetes. J. Clin. Endocrinol. Metab. 85:715-719.

Baumgard, L. H., B. A. Corl, D. A. Dwyer, and D. E. Bauman. 2002. Effects of conjugated linoleic acids (CLA) on tissue response to homeostatic signals and plasma variables associated with lipid metabolism in lactating dairy cows. J. Anim. Sci. 80:1285-1293.

Beam, S. W., and W. R. Butler. 1997. Energy balance and ovarian follicle development prior to the first ovulation postpartum in dairy cows receiving three levels of dietary fat. Biol. Reprod. 56:133-142.

Block, S. S., W. R. Butler, R. A. Ehrhardt, A. W. Bell, M. E. Van Amburgh, and Y. R. Boisclair. 2001. Decreased concentration of plasma leptin in periparturient dairy cows is caused by negative energy balance. J. Endocrinol. 171:339-348.

Block, S. S., R. P. Rhoads, D. E. Bauman, R. A. Ehrhardt, M. A. McGuire, B. A. Crooker, J. M. Griinari, T. R. Mackle, W. J. Weber, M. E. Van Amburgh, and Y. R. Boisclair. 2003. Demonstration of a role for insulin in the regulation of leptin in lactating dairy cows. J. Dairy Sci. (accepted).

Boisclair, Y. R., D. E. Bauman, A. W. Bell, F. R. Dunshea, and M. Harkins. 1994. Nutrient utilization and protein turnover in the hindlimb of cattle treated with bovine somatotropin. J. Nutr. 124:664-673.

Bronson, F. H. 2001. Puberty in female mice is not associated with increases in either body fat or leptin. Endocrinology 142:47584761.

Chehab, F. F., M. E. Lim, and R. Lu. 1996. Correction of the sterility defect in homozygous obese female mice by treatment with the human recombinant leptin. Nat. Genet. 12:318-320.
Cheung, C. C., J. E. Thornton, J. L. Kuijper, D. S. Weigle, D. K. Clifton, and R. A. Steiner. 1997. Leptin is a metabolic gate for the onset of puberty in the female rat. Endocrinology 138:855.

Cheung, C. C., J. E. Thornton, S. D. Nurani, D. K. Clifton, and R. A. Steiner. 2001. A reassessment of leptin's role in triggering the onset of puberty in the rat and mouse. Neuroendocrinology $74: 12-21$.

Chilliard, Y., M. Bonnet, C. Delavaud, Y. Faulconnier, C. Leroux, J. Djiane, and F. Bocquier. 2001. Leptin in ruminants. Gene expression in adipose tissue and mammary gland, and regulation of plasma concentration. Domest. Anim. Endocrinol. 21:271-295.

Cunningham, M. J., D. K. Clifton, and R. A. Steiner. 1999. Leptin's action on the reproductive axis: Perspectives and mechanisms. Biol. Reprod. 60:216-222.

Delavaud, C., F. Bocquier, Y. Chilliard, D. H. Keisler, A. Gertler, and G. Kann. 2000. Plasma leptin determination in ruminants: Effect of nutritional status and body fatness on plasma leptin concentration assessed by a specific RIA in sheep. J. Endocrinol. 165:519-526.

Devaskar, S. U., C. Ollesch, R. A. Rajakumar, and P. A. Rajakumar. 1997. Developmental changes in ob gene expression and circulating leptin peptide concentrations. Biochem. Biophys. Res. Commun. 238:44-47.

Diaz, M. C., M. E. Van Amburgh, J. M. Smith, J. M. Kelsey, and E. L. Hutten. 2001. Composition of growth of Holstein calves fed milk replacer from birth to 105-kilogram body weight. J. Dairy Sci. 84:830-842.

Diaz-Torga, G. S., M. E. Mejia, A. Gonzalez-Iglesias, N. Formia, D. Becu-Villalobos, and I. M. Lacau-Mengido. 2001. Metabolic cues for puberty onset in free grazing Holstein heifers naturally infected with nematodes. Theriogenology 56:111-122.

Ehrhardt, R. A., A. W. Bell, and Y. R. Boisclair. 2002. Spatial and developmental regulation of leptin in fetal sheep. Am. J. Physiol. 282:R1628-1635.

Ehrhardt, R. A., P. L. Greenwood, R. M. Slepetis, A. W. Bell, and Y. R. Boisclair. 2001. Postnatal nutrition and fatness affect plasma leptin concentration in neonatal sheep. J. Dairy Sci. 84(Suppl. 1):934. (Abstr.)

Ehrhardt, R. A., R. M. Slepetis, M. E. Van Amburgh, J. Siegal-Willot, A. W. Bell, and Y. R. Boisclair. 2000. Development of a specific radioimmunoassay to measure physiological changes of circulating leptin in cattle and sheep. J. Endocrinol. 166:519-528.

Engelbregt, M. J., M. M. van Weissenbruch, C. Popp-Snijders, P. Lips, and H. A. Delemarre-van de Waal. 2001. Body mass index, body composition, and leptin at onset of puberty in male and female rats after intrauterine growth retardation and after early postnatal food restriction. Pediatr. Res. 50:474-478.

Faggioni, R., K. R. Feingold, and C. Grunfeld. 2001. Leptin regulation of the immune response and the immunodeficiency of malnutrition. FASEB J. 15:2565-2571.

Farooqi, I. S., S. A. Jebb, G. Langmack, E. Lawrence, C. H. Cheetham, A. M. Prentice, I. A. Hughes, M. A. McCamish, and S. O'Rahilly. 1999. Effects of recombinant leptin therapy in a child with congenital leptin deficiency. New Engl. J. Med. 16:879-884.

Farooqi, I. S., G. Matarese, G. M. Lord, J. M. Keogh, E. Lawrence, C. Agwu, V. Sanna, S. A. Jebb, F. Perna, S. Fontana, R. I. Lechler, A. M. DePaoli, and S. O'Rahilly. 2002. Beneficial effects of leptin on obesity, T cell hyporesponsiveness, and neuroendocrine/metabolic dysfunction of human congenital leptin deficiency. J. Clin. Invest. 110:1093-1103.

Flier, J. S. 1998. What's in a name? In search of leptin's physiologic role. J. Clin. Endocrinol. Metab. 83:1407-1413.

Foster, D. L., and S. Nagatani. 1999. Physiological perspectives on leptin as a regulator of reproduction: Role in timing puberty. Biol. Reprod. 60:205-215.

Fox, D. G., T. P. Tylutki, M. E. Van Amburgh, L. E. Chase, A. N. Pell, T. R. Overton, L. O. Tedeschi, C. N. Rasmussen, and V. M. Durbal. 2000. The net carbohydrate and protein system for evaluating herd nutrition and nutrient excretion. Animal Science Mimeo 213, Department of Animal Sciences, Cornell University, Ithaca, NY. 
Garcia, M. R., M. Amstalden, S. W. Williams, R. L. Stanko, C. D. Morrison, D. H. Keisler, S. E. Nizielski, and G. L. Williams. 2002. Serum leptin and its adipose gene expression during pubertal development, the estrous cycle, and different seasons in cattle. J. Anim. Sci. 80:2158-2167.

Henry, B. A., J. W. Goding, W. S. Alexander, A. J. Tilbrook, B. J. Canny, F. Dunshea, A. Rao, A. Mansell, and I. J. Clarke. 1999. Central administration of leptin to ovariectomized ewes inhibits food intake without affecting the secretion of hormones from the pituitary gland: Evidence for a dissociation of effects on appetite and neuroendocrine function. Endocrinology 140:1175-1182.

Huynh, H. T., G. Robitaille, and J. D. Turner. 1991. Establishment of bovine mammary epithelial cells (MAC-T): An in vitro model for bovine lactation. Exp. Cell Res. 197:191-199.

Ingvartsen, K. L., and Y. R. Boisclair. 2001. Leptin and the regulation of food intake, energy homeostasis and immunity with special focus on perparturient ruminants. Domest. Anim. Endocrinol. 21:215-250.

Jackson, L. M., T. Ichimaru, C. A. Jaffe, and D. L. Foster. 2002. Effects of leptin on LH secretion during developmental and nutritional hypogonadotropism. 84th Annu. Mtg. Endocrine Soc. 84:125. (Abstr.)

Keuhn, C. S., D. E. Otterby, and J. G. Linn. 1994. The effect of dietary energy concentration on calf performance. J. Dairy Sci. 77:2621-2629.

Leury, B. J., L. H. Baumgard, S. S. Block, N. Segoalc, R. A. Ehrhardt, R. P. Rhoads, D. E. Bauman, A. W. Bell, and Y. R. Boisclair. 2003. Effect of insulin and growth hormone on plasma leptin in the periparturient dairy cows. Am. J. Physiol. 285:(accepted).

McFadin, E. L., C. D. Morrison, P. R. Buff, N. C. Whitley, and D. H. Keisler. 2002. Leptin concentrations in periparturient ewes and their subsequent offspring. J. Anim. Sci. 80:738-743.

Morrison, C. D., R. Wood, E. L. McFadin, N. C. Whitley, and D. H. Keisler. 2002. Effect of intravenous infusion of recombinant ovine leptin on feed intake and serum concentrations of GH, LH, insulin, IGF-1, cortisol, and thyroxine in growing prepubertal ewe lambs. Domest. Anim. Endocrinol. 22:103-112.

Mounzih, K., R. Lu, and F. F. Chehab. 1997. Leptin treatment rescues the sterility of genetically obese ob/ob males. Endocrinology 138:1190-1193.

Mühlhäusler, B. S., C. T. Roberts, J. R. McFarlane, K. G. Kauter, and I. C. McMillen. 2002. Fetal leptin is a signal of fat mass independent of maternal nutrition in ewes fed at or above maintenance energy requirements. Biol. Reprod. 67:493-499.

National Research Council. 2001. Nutrient Requirements of Dairy Cattle. 7th rev. ed. Natl. Acad. Sci., Washington, DC.
Pardini, V. C., I. M. N. Victoria, S. M. V. Rocha, D. G. Andrade, A. M. Rocha, F. B. Pieroni, G. Milagres, S. Purisch, and G. Velho. 1998. Leptin levels, b-cell function, and insulin sensitivity in families with congenital and acquired generalized lipoatropic diabetes. J. Clin. Endocrinol. Metab. 83:503-508.

Plant, T. M. 2001. Leptin, growth hormone, and the onset of primate puberty. J. Clin. Endocrinol. Metab. 86:458-460.

Purup, S., and K. Sejrsen. 2000. Influence of leptin on proliferation of bovine mammary epithelial cells in collagen gel culture. Page 230 in Book of Abstracts of the 51st Annual Meeting of the European Association for Animal Production. Van Arendonk, J. A. M., A. Hofer, Y. van der Honing, F. Madec, K. Sejrsen, D. Pullar, L. Bodin, J. A. Fernandez, E. W. Bruns, ed. Wageningen prs, The Hague, The Netherlands.

Radcliff, R. P., M. J. Vandehaar, L. T. Chapin, T. E. Pilbeam, D. K. Beede, E. P. Stanisiewski, and H. A. Tucker. 2000. Effects of diet and injection of bovine somatotropin on prepubertal growth and first-lactation milk yields of Holstein cows. J. Dairy Sci. 83:23-29.

Saad, M. F., S. Damani, R. L. Gingerich, M. G. Riad-Gabriel, A. Khan, R. Boyadjian, S. D. Jinagouda, K. El-Tawil, R. K. Rude, and V. Kamdar. 1997. Sexual dimorphism in plasma leptin concentration. J. Clin. Endocrinol. Metab. 82:579-584.

Sejrsen, K., S. Purup, M. Vestergaard, and J. Foldager. 2000. High body weight gain and reduced bovine mammary growth: Physiological basis and implications for milk yield potential. Domest. Anim. Endocrinol. 19:93-104.

Silva, L. F. P., M. J. Vandehaar, M. S. Weber Nielsen, and G. E. W. Smith. 2002. Evidence for a local effect of leptin in bovine mammary gland. J. Dairy Sci. 85:3277-3286.

Spicer, L. J. 2001. Leptin: A possible metabolic signal affecting reproduction. Domest. Anim. Endocrinol. 21:251-270.

Spiegelman, B. M., and J. S. Flier. 2001. Obesity and the regulation of energy balance. Cell 104:531-543.

Watanobe, H., and H. B. Schioth. 2002. Postnatal profile of plasma leptin concentrations in male and female rats: Relation with the maturation of the pituitary-gonadal axis. Regul. Pept. 105:23-28.

Williams, G. L., M. Amstalden, M. R. Garcia, R. L. Stanko, S. E. Nizielski, C. D. Morrison, and D. H. Keisler. 2002. Leptin and its role in the central regulation of reproduction in cattle. Domest. Anim. Endocrinol. 23:339-349.

Yuen, B. S. J., P. C. Owens, J. R. McFarlane, M. E. Symonds, L. J. Edwards, K. G. Kauter, and I. C. McMillen. 2002. Circulating leptin concentrations are positively related to leptin messenger RNA expression in the adipose tissue of fetal sheep in the pregnant ewe fed at or below maintenance energy requirements during late gestation. Biol. Reprod. 67:911-916. 